\title{
Monitoring of Mercury in Air from the Abandoned Mercury Mine Area using Direct Mercury Analyzer
}

\author{
Jessie O. Samaniego, Cris Reven L. Gibaga, Alexandria M. Tanciongco and Rasty M. Rastrullo \\ Department of Science and Technology - Philippine Nuclear Research Institute, \\ Commonwealth Ave., Quezon City, 1101, Philippines. \\ ORCID ID: 0000-0003-1020-6224 (JO Samaniego) \\ ORCID ID: 0000-0001-7906-7993 (CRL Gibaga) \\ ORCID ID: 0000-0002-6585-5419 (AM Tanciongco) \\ ORCID ID: 0000-0002-1964-7694 (RM Rastrullo)
}

\begin{abstract}
The abandoned mercury mine area in Puerto Princesa City, Philippines was included in the list of abandoned and inactive mines in the Philippines that was characterized with high risk to human health and the environment because of its bare and unvegetated soils. In this study, total mercury in the ambient air was measured to assess the distribution of it in the vicinity of the mine. A rapid monitoring of mercury in the area was conducted using handheld air sampling pump with sorbent trap positioned above the ground during dry and wet seasons in 2019. Mercury in sorbent traps were analyzed by direct mercury analyzer. Results showed that during dry season, the site with the highest mercury concentrations $(2,035-2,138$ $\mathrm{ng} / \mathrm{m}^{3}$ ) in the air was located at the mine waste calcine deposits, exposed natural soils and rock outcrops, northeast of the pit lake. Air collected from the perimeter of pit lake has mercury concentrations of $8.44-61.63 \mathrm{ng} / \mathrm{m}^{3}$ which is close to the concentrations reported in 2002. During wet season sampling, lower mercury concentrations $\left(9.13-65.86 \mathrm{ng} / \mathrm{m}^{3}\right)$ were measured near the mine waste calcine deposit which suggest that particulate pollutants, including mercury, were washed out by precipitation. Results from this study suggest that monitoring of mercury in the air using a handheld sampler with sorbent followed by direct mercury analyzer can be a useful method for the rapid measurement of mercury concentrations which can be used for risk assessment of mercury exposure from air.
\end{abstract}

Keywords: Abandoned mine, Direct mercury analyzer, Mercury, Air pollution, Palawan

\section{INTRODUCTION}

A naturally occurring heavy metals such as mercury $(\mathrm{Hg})$, are released to the environment by mining and other industrial operations. Mercury is considered as pollutant that affects human and ecosystem as it cycles in the environment on a global scale [1], [2]. The release of processed $\mathrm{Hg}$ into the soil, water and air is further amplified by coal-fired power plants, waste incinerators and mining of mercury, gold and other metals [3] - [6]. Mercury and other $\mathrm{Hg}$ species are hazardous air pollutant as it bio-accumulate and persist to human bodies if inhaled. Long-term exposure to $\mathrm{Hg}$ vapor may be toxic on the human body as it affects some systems of the human body as well as internal and external organs such as lungs and skin [7]. Abandoned and enriched open $\mathrm{Hg}$ mines, which are natural but considered permanent source of $\mathrm{Hg}$ emissions to the global atmosphere, are however a minor contributor at $5 \%$ of total global Hg emissions [5], [8].

Abandoned and operational $\mathrm{Hg}$ mines are considered major source of $\mathrm{Hg}$ pollution in the environment because it releases mine wastes, tailings and vapor with high concentration of $\mathrm{Hg}$ as reported from several $\mathrm{Hg}$ mines around the world [9], [10]. In the Philippines, the only $\mathrm{Hg}$ mine site is in Puerto Princesa City in Palawan Island. Mercury in this mine mostly occurs in cinnabar $(\mathrm{HgS})$ ores hosted by opalite bodies deposited along fractures and weak zones in the bedrock [11]. The $\mathrm{Hg}$ deposit was mined by the Palawan Quicksilver Mines, Incorporated (PQMI) from 1953 and abandoned in 1976. During the mining operations, an estimated large amount of waste rocks and tailings with high concentration of $\mathrm{Hg}$ (up to $924 \mathrm{mg} / \mathrm{kg}$ ) were left out in the open area near the PQMI pit lake [12], [13]. These materials are exposed to the environment that $\mathrm{Hg}$ can be leached out into water systems by rainfall, enter the soil matrix and emit to the atmosphere by volatilization and as particlebound $\mathrm{Hg}$.

Currently, the abandoned $\mathrm{Hg}$ mine is included in the abandoned and inactive mines in the Philippines that are assessed with high risk to human health and the environment and it requires rehabilitation [14]. Exposure of the local population to $\mathrm{Hg}$, which is around 12,000 in 2015 , to $\mathrm{Hg}$ may occur due to inhalation of $\mathrm{Hg}$ present in air and consumption of $\mathrm{Hg}$ contaminated food and water. Previous air quality studies in the PQMI area reported $\mathrm{Hg}$ concentrations of $64.9 \mathrm{ng} / \mathrm{m}^{3}$ in 2002 [12] and $3.04-49.27 \mathrm{ng} / \mathrm{m}^{3}$ in 2006 [15].

Former $\mathrm{Hg}$ mining sites are considered anthropogenic sources of the emission of gaseous $\mathrm{Hg}$, which is mainly volatile elemental $\mathrm{Hg}\left(\mathrm{Hg}^{0}\right)$, in the surrounding environment [16]. This was exhibited in the measured $\mathrm{Hg}$ vapor in the former mining area of Abbadia San Salvatore in Mount Amiata in Central Italy facilities and the vicinities of the former mining structures [17]. At Almaden $\mathrm{Hg}$ mine site in Spain, high $\mathrm{Hg}$ concentration in cinnabar ore caused the increase in the $\mathrm{Hg}$ level in air at the 
workplaces [18]. The levels of gaseous $\mathrm{Hg}$ concentration are different in ambient air, range of $1-3 \mathrm{ng} / \mathrm{m}^{3}, 3-5 \mathrm{ng} / \mathrm{m}^{3}$, and $>5 \mathrm{ng} / \mathrm{m}^{3}$ in the rural, urban, and industrial regions, respectively, while its background concentrations are typically ranged from 1.6 to $1.8 \mathrm{ng} / \mathrm{m}^{3}$ in the Northern Hemisphere and from 1.1 to $1.4 \mathrm{ng} / \mathrm{m}^{3}$ in the Southern Hemisphere [19].

Recently, international efforts have been mounted to control $\mathrm{Hg}$ emissions, most notably under the Minamata Convention on Mercury that came into force in 2017, in which Philippines is one of the signatories. In this study, $\mathrm{Hg}$ emitted in the atmosphere from the mine area, including mine waste calcine deposits in the vicinity of the former PQMI mine area, was measured in dry and wet seasons to assess its concentration seasonal variation. This study has been carried out in the vicinities of abandoned $\mathrm{Hg}$ mine area in Puerto Princesa City, Philippines in 2019.

\section{MATERIALS AND METHODS}

\section{II.I Study Area}

The abandoned Hg mine site is in Puerto Princesa City located in the central part of Palawan Island. It is bound to the east by the Sulu Sea and to the west by the South China Sea (Fig. 1). The abandoned $\mathrm{Hg}$ mine site is located approximately $14 \mathrm{~km}$ north from the city center of Puerto Princesa. The area where a reported human risk on $\mathrm{Hg}$ contamination encompasses two (2) villages namely Santa Lourdes and Tagburos. These areas are situated within the catchment of the Tagburos River and it is approximately $3 \mathrm{~km}$ west of Honda Bay coast, which is a local fishery and tourist recreational area. Puerto Princesa City is included in Philippines Type 3 climate, which is relatively dry from November to April, and wet during the rest of the year [20]. Located in this city is the naturally occurring $\mathrm{Hg}$ deposit hosted by Tagburos Opalite Formation. Cinnabar in this deposit was mined from 1953 and abandoned in 1976 with exposed open mine pit left, which is now filled with water forming a lake (Fig. 2). Mine waste calcines produced during the operation were used to construct a wharf in nearby Honda Bay to serve as port for mining operations. This wharf is now used as port for tourist and fishing boats. Other mine waste calcines were stockpiled and scattered in the northeast area of the pit lake shore.

\section{II.II Air Sampling}

Collection of air samples in the PQMI mine area and vicinities were done in two (2) seasons, April 2019 for dry season and July 2019 for wet season. Air samples were collected near the target sampling points based on the prepared sampling grid and its accessibility over the study area. A larger sampling interval $(2 \mathrm{~km})$ was used in the wet season compared to the dry season $(0.5 \mathrm{~km})$ as shown in Fig. 3. Air sampling was done by filtering the gaseous $\mathrm{Hg}$ from a known volume of the surrounding ambient air. Personal air sample pump was used to pump in air at a known flow rate, shown in Fig. 4a. Parameters including temperature and pressure were recorded by the device to calculate the volume of air that passed through at standard temperature and pressure (STP) conditions. A sorbent trap is attached at the end of the inlet tube of the air pump. The sorbent

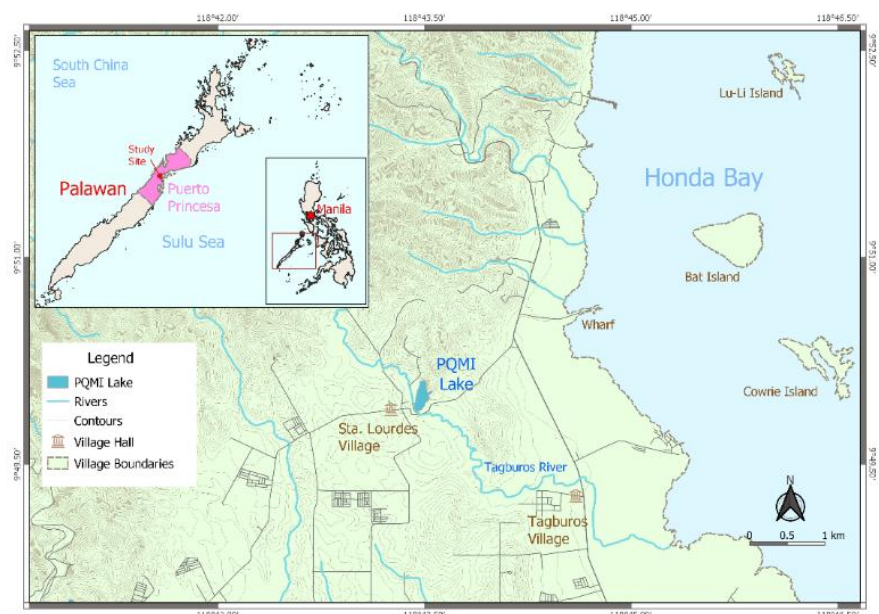

Fig. 1. Map of the study site showing the rivers, pit lake, and Honda Bay, with a map of the Philippines and Palawan island (inset)

traps consist of approximately 1-inch long quartz tube filled with about $300 \mathrm{mg}$ of adsorbent material (Fig. 4b). As the air goes in, the adsorbent will trap the impurities in the air, mainly heavy metals. The sorbent will also contain the mass concentration of $\mathrm{Hg}$ in gases, including elemental mercury $\left(\mathrm{Hg}^{0}\right)$ and oxidized forms of $\mathrm{Hg}\left(\mathrm{Hg}^{2+}\right)$. Meteorological data during the collection of air samples were gathered from the Puerto Princesa City weather station of the Philippine Atmospheric, Geophysical and Astronomical Services Administration (PAGASA). Table 1 shows the average temperature during sampling, relative humidity, wind direction, wind speed and weather condition. Air sampling was performed between 9:00 in the morning and 4:00 in the afternoon during every sampling day. At each sampling site, air pump was held at $1 \mathrm{~m}$ above the ground and maintained at a vertical position. Air suction was done for 20 minutes per sampling site at a flow rate of 500 $\mathrm{mL} / \mathrm{min}$, therefore collecting $10 \mathrm{~L}$ of air. A total of 48 points (29 points in April, and 19 points in July) were sampled and each sorbent trap used was safely stored and brought to the laboratory for $\mathrm{Hg}$ analysis.

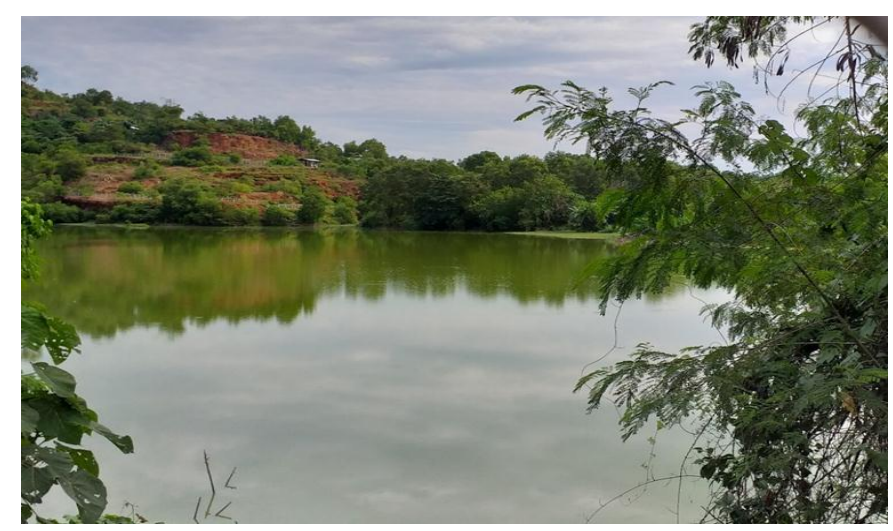

Fig. 2. PQMI pit lake and mine waste calcine deposits near the lakeshore. 
Table 1. Average meteorological conditions during air sampling at PQMI mine area and vicinity

\begin{tabular}{|c|c|c|}
\hline Parameter & $\begin{array}{c}\text { April 2019 } \\
\text { (dry season) }\end{array}$ & $\begin{array}{c}\text { July 2019 } \\
\text { (wet season) }\end{array}$ \\
\hline Temperature $\left({ }^{0} \mathrm{C}\right)$ & & \\
\hline Minimum & 26.2 & 25.0 \\
\hline Maximum & 33.9 & 32.4 \\
\hline Average & 30.1 & 28.8 \\
\hline Wind & & \\
\hline Direction & $\mathrm{E}$ & $\mathrm{W}$ \\
\hline Speed $(\mathrm{m} / \mathrm{s})$ & 2.0 & 2.0 \\
\hline Condition & Sunny & Cloudy \\
\hline
\end{tabular}

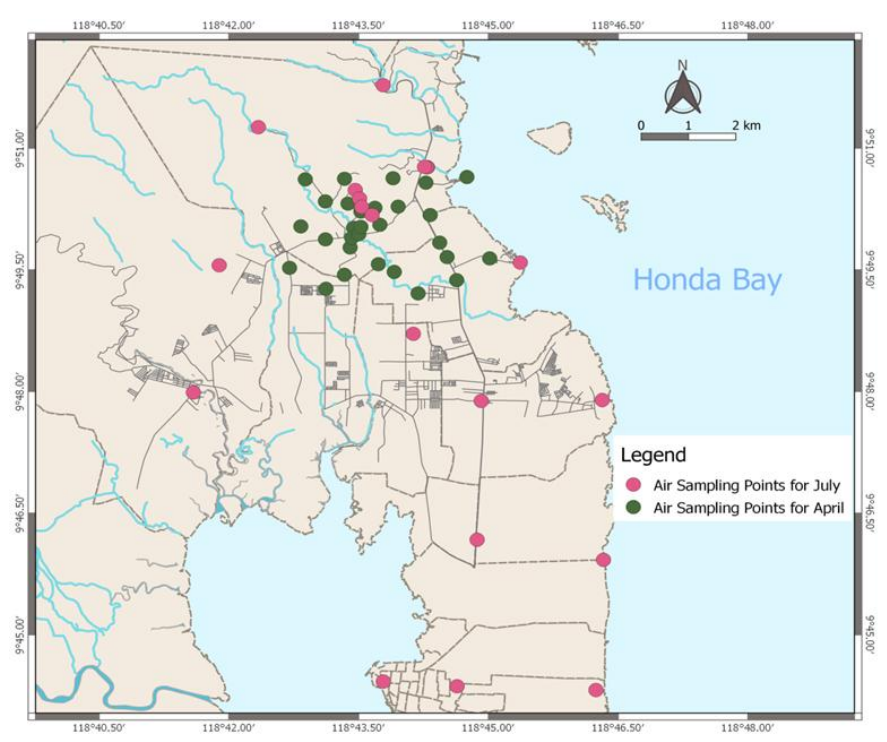

Fig. 3. Location map of sampling points for mercury concentration in the ambient air

\section{II.III Mercury Analysis}

A direct mercury analyzer DMA- $80^{\circledR}$ (Milestone, Italy) was used in the analyses of $\mathrm{Hg}$ in the study (Fig. 5). This direct mercury analyzer can determine total mercury (THg) concentrations in solid, liquid and gas samples and was applied in various environmental studies [21] - [23]. The sorbent tubes are directly placed without other sample preparation on the auto-sampler and introduced in the direct mercury analyzer where it is initially dried and then thermally heated at around $650^{\circ} \mathrm{C}$ in a continuous flow of oxygen as the carrier gas. Gaseous combustion products were carried through a heated catalyst, where $\mathrm{Hg}$ species are converted to elemental $\mathrm{Hg}$ vapor $\left(\mathrm{Hg}^{0}\right)$, and where halogens and other species which can interfere with the analysis are trapped. Mercury vapor and other decomposition products were carried to a glass tube goldcoated sand where $\mathrm{Hg}^{0}$ is selectively trapped. Later, the trap is rapidly heated to release $\mathrm{Hg}^{0}$ vapor into a single beam spectrophotometer. The $\mathrm{Hg}$ concentration is determined using atomic absorption spectrometry at $254 \mathrm{~nm}$ and the weight of the sample.
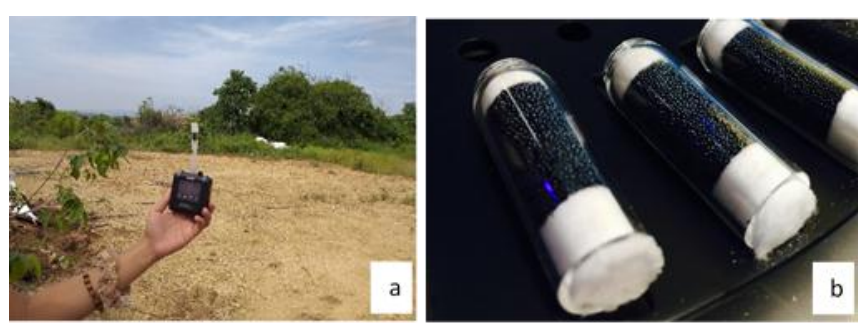

Fig. 4. (a) Air sampling using handheld personal sampling pump, (b) and adsorbent traps for Milestone DMA-80

\section{II-IV Geostatistical Method}

All sampling points for $\mathrm{THg}$ measurement in the atmosphere were interpolated using the natural neighbor method to produce a map of atmospheric $\mathrm{Hg}$ concentration in the area. The natural neighbor interpolation, also known as Sibson Interpolation, is a method that works by applying the weights of adjacent points from the original sample point. This method is local and only uses the average of samples surrounding the query point. The interpolated heights are guaranteed to be within the range of the samples used [24]. Unknown points are inferred based from the weights of the known samples that surround it.

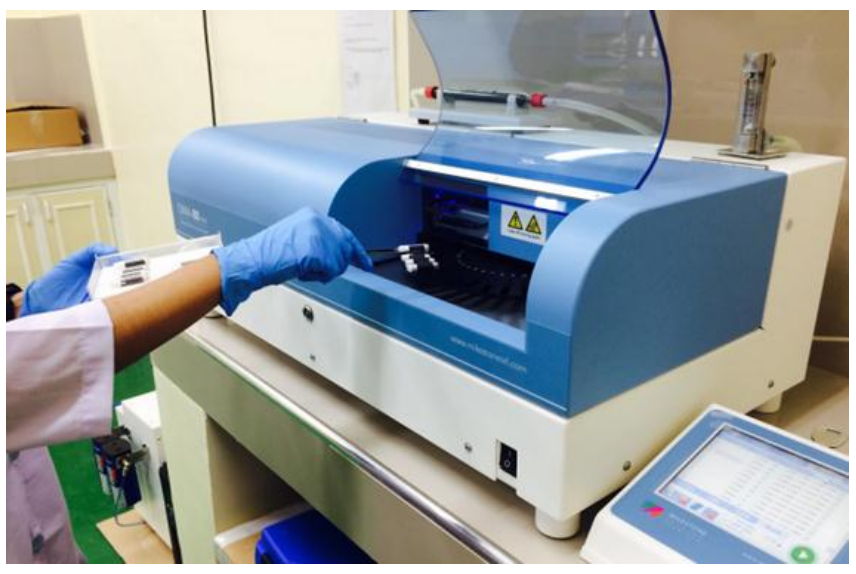

Fig. 5. Direct mercury analyzer used in the analysis

\section{RESULTS AND DISCUSSION}

Gaseous elemental mercury is the main chemical $\mathrm{Hg}$ species released into the atmosphere by volatilization. It is characterized as very stable, low water solubility, volatile at room temperature and relatively inert to chemical reactions with other atmospheric components. Mercury released in the atmosphere stayed for about one year, it is enough time to be dispersed or transported to greater distances before being deposited back in the terrestrial and aquatic ecosystems [25].

\section{III-I Total Hg Concentrations in Dry Season}

The measurement and distribution of $\mathrm{THg}$ concentrations in the atmosphere of abandoned mine area and vicinities during dry season are presented in map shown in Fig. 6. Results show that the sites with the highest $\mathrm{Hg}$ concentration in the air $(2,035-$ 
$2,138 \mathrm{ng} / \mathrm{m}^{3}$ ) were measured at the mine waste calcine deposits and with exposed soils and rock outcrops, northeast of pit lake (Fig. 7). This high $\mathrm{Hg}$ distribution in the air is not only related to exposure of mine waste calcines but also caused by the exposure of natural soils and rock outcrops. Located near the landfill area is also found to have outcrops of Tagburos Opalite next to serpentinite rock is also contributing to the $\mathrm{Hg}$ emission to the atmosphere.

Air samples collected from the perimeter of the pit lake has $\mathrm{THg}$ concentrations of $8.44-61.63 \mathrm{ng} / \mathrm{m}^{3}$ which is close to the concentrations $\left(64.9 \mathrm{ng} / \mathrm{m}^{3}\right)$ reported in 2002 [12]. Concentrations of $\mathrm{Hg}$ in the air collected from the rest of the mine area, including Honda Bay, have relatively lower concentrations $\left(4.07-12.72 \mathrm{ng} / \mathrm{m}^{3}\right)$ but still high compared to the global background of $\mathrm{Hg}$ which is $1.0-3.0 \mathrm{ng} / \mathrm{m}^{3}$ for rural areas. Total $\mathrm{Hg}$ concentrations are relatively low in the Honda Bay wharf, even though it was constructed made of mine waste calcines, possibly due to the encapsulation of $\mathrm{Hg}$ by the concrete pavements and roads within the wharf. The presence of gaseous $\mathrm{Hg}$ circulating in the air in this area can be inferred that there is a continuous volatilization from the soils with high $\mathrm{Hg}$ concentration. The population near this site is the most affected by a constant direct contact with this gas through inhalation, which is a health hazard.

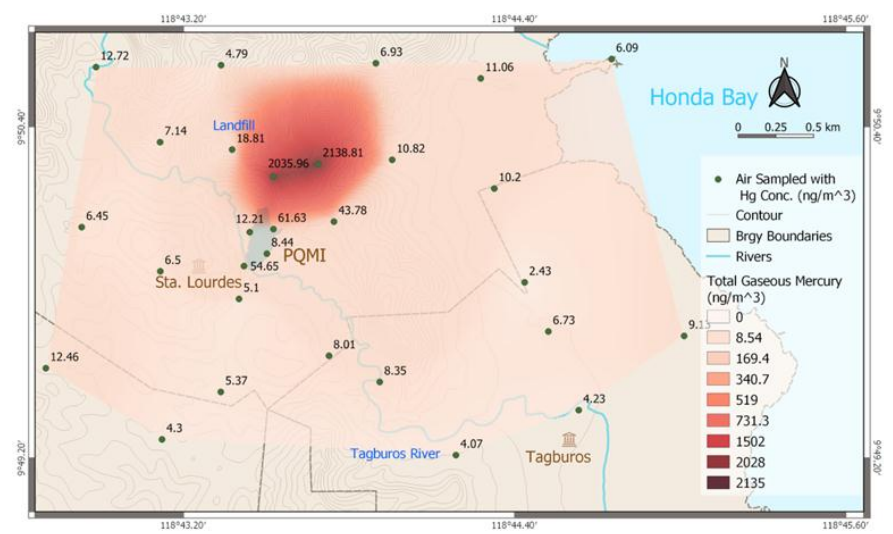

Fig. 6. Map showing the distribution of $\mathrm{THg}$ concentration in PQMI mine area during dry season.

\section{III-II Total Hg Concentrations in Wet Season}

The measured THg in the air during the wet season sampling campaign is presented in Fig. 8. The coverage of the sampling was extended to the western and northern part of PQMI area and at Puerto Princesa City center. At the western and northern mountainous part of PQMI area, the measured $\mathrm{THg}$ in air is in the range of 7.18 to $74.67 \mathrm{ng} / \mathrm{m}^{3}$, while at the city proper the measured range of $\mathrm{THg}$ concentration is $<1-37.99 \mathrm{ng} / \mathrm{m}^{3}$. Some of the sampling sites in the city center were in the streets, where the motor vehicle emissions as well as household and industrial emissions contributed to the total $\mathrm{Hg}$ measured during sampling. Ideally, particulate matters during rainy season is lower than dry season as the particulate pollutants were washed out by precipitation [26]. At the PQMI area, the $\mathrm{THg}$ in air measured with the range of $9.13-65.86 \mathrm{ng} / \mathrm{m}^{3}$, which is lower concentration of THg measured near the area

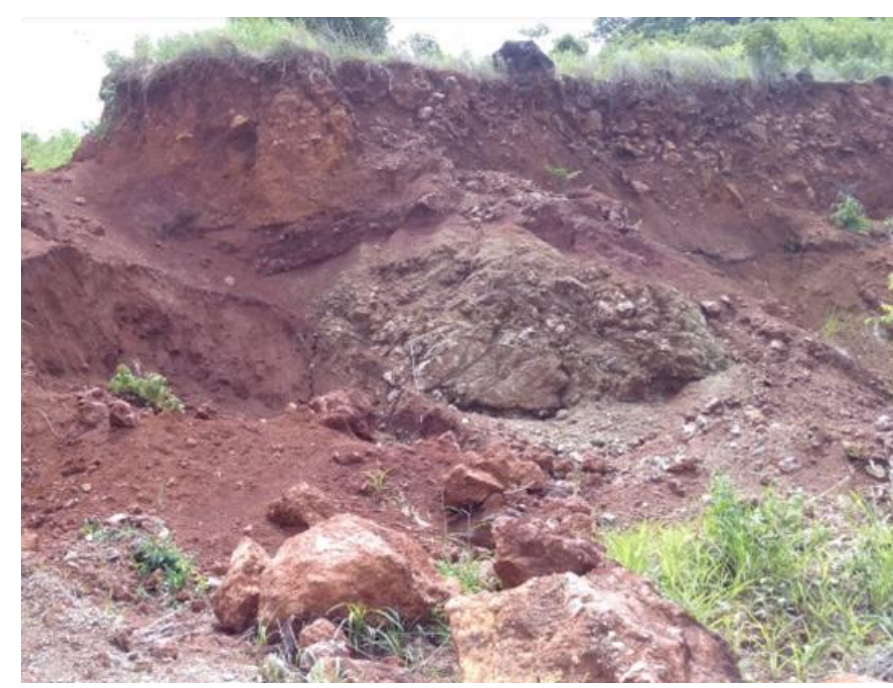

Fig. 7. Rock exposure of Tagburos Opalite near the landfill area with high $\mathrm{THg}$ concentrations

than the same area where high $\mathrm{Hg}$ concentration in the air measured during dry season. The main factors that determine the $\mathrm{THg}$ in the ambient air are the $\mathrm{Hg}$ speciation and the concentration in topsoil [27]. Furthermore, the THg in the air is also related to soil temperature, soil moisture, solar radiation, rainfall and wind direction and speed [28] - [30]. During the wet season, the emission of particle-bound $\mathrm{Hg}$ is reduced because of the effect of rainfall on washing out the particulate pollutants and deposited in the sediments of rivers and lakes. While wet deposition by precipitation is considered as one of the main mechanisms for removal of aerosols from the atmosphere [31]. Although, previous studies suggest that there are increases in $\mathrm{Hg}$ volatilization from naturally enriched soils due to the precipitation events which have been observed in the field [32] but other studies indicate that further research on the exact mechanisms responsible for the increased fluxes are required [33].

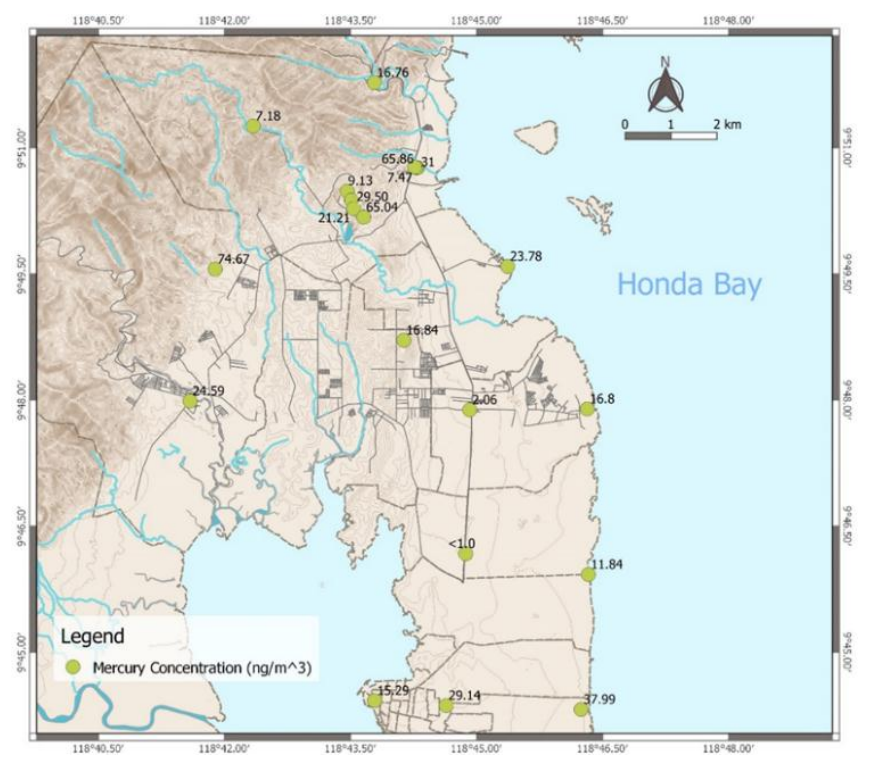

Fig. 8. Map showing the distribution of THg concentrations in the atmosphere of the abandoned $\mathrm{Hg}$ mine area and the Puerto Princesa City during wet season 
International Journal of Engineering Research and Technology. ISSN 0974-3154, Volume 13, Number 6 (2020), pp. 1373-1378

(C) International Research Publication House. https://dx.doi.org/10.37624/IJERT/13.6.2020.1373-1378

\section{CONCLUSION}

This study focused on the distribution of mercury emitted into the atmosphere by anthropogenic source - the abandoned PQMI mine area - by evaluating the measured concentrations as an indicator of air quality. The abandoned $\mathrm{Hg}$ mine left large amount of mine waste calcine deposited and scattered in the vicinity that directly affect the air quality in the mine area. Elevated THg concentrations $\left(2,035-2,138 \mathrm{ng} / \mathrm{m}^{3}\right)$ in the air were measured during dry season at the area near the mine waste calcine deposits and exposed natural soils and rock outcrops located northeast of the PQMI pit lake. Significant $\mathrm{THg}$ concentrations were recorded in the perimeter of the PQMI pit lake while the rest of the study area, including Honda Bay, has relatively lower concentrations but still high compared to the global background of gaseous $\mathrm{Hg}$ for rural areas. These elevated $\mathrm{Hg}$ concentrations in the area were attributed to the scattered mine waste calcines that are possibly releasing gaseous $\mathrm{Hg}$ due to continuous volatilization from the mercury laden soils and the particle-bound $\mathrm{Hg}$ from the bare and unvegetated areas. During the wet season sampling, lower $\mathrm{THg}$ concentrations $\left(9.13-65.86 \mathrm{ng} / \mathrm{m}^{3}\right)$ were measured near the mine waste calcines deposit. This suggest that particulate pollutants, including $\mathrm{Hg}$ were washed out by precipitation and further deposited in river and lake sediments and released to the atmosphere. The finding, however, is contrast to the conclusion of previous studies that suggest increases in $\mathrm{Hg}$ volatilization from naturally enriched soils due to the precipitation events. Results of this study suggest that monitoring of $\mathrm{Hg}$ in air using a handheld air sampler with sorbent followed by direct mercury analyzer can be a useful method for the rapid measurement and mapping of $\mathrm{Hg}$ pollution in the atmosphere. Further recommendation is to increase the sampling points while decreasing the sampling interval to get a higher resolution of the mercury distribution in the air of the vicinity. An increase in the frequency of monitoring to one year will also increase the temporal resolution of $\mathrm{Hg}$ in air that would lead to better seasonal observation. Measured $\mathrm{Hg}$ concentrations from this study can be used as input in calculating the chronic daily intake by the human living in the area as part of general risk assessment.

\section{ACKNOWLEDGMENT}

The authors acknowledge the Department of Science of Technology - Grants-in-Aid Program (DOST-GIA) for the project grants. Special appreciations are given to the Philippine Council for Industry, Energy and Emerging Technology Research and Development (DOST-PCIEERD) and Provincial Science and Technology Center of Palawan for the project monitoring and technical support.

\section{REFERENCES}

[1] Driscoll C, Mason R, Chan H, Jacob D, Pirrone N. Mercury as a global pollutant: Sources, pathways, and effects. Environ. Sci. Technol. 2013; 47: 4967-4983.

[2] Sheu G, Gay D, Schmeltz D, Olson M, Chang S, Lin D, Nguyen L. A new monitoring effort for Asia: The Asia Pacific Mercury Monitoring Network (APMMN). Atmosphere 2019; 10: 1-7.
[3] Bhan A, Sarkar N. Mercury in the environment: Effect on health and reproduction. Rev. Environ. Health 2005; 20(1): 39-56.

[4] Beckers F, Rinklebe J. Cycling of mercury in the environment: Sources, fate, and human health implications: A review. Crit. Rev. Environ. Sci. Technol. 2017; 47(9): 693-794.

[5] Pirrone N, Cinnirella S, Feng X, Finkelman R, Friedli H, Leaner J, Mason R, Mukherjee A, Stracher G, Streets D, Telmer K. Global mercury emissions to the atmosphere from anthropogenic and natural sources. Atmos. Chem. Phys. 2010; 10: 5951-5964.

[6] Samaniego J, Tanchuling MA. Physico-chemical Characteristics of Wastewater from a Ball Mill Facility in Small-Scale Gold Mining Area of Paracale, Camarines Norte, Philippines. Philippine Journal of Science 2018; 147(3): 343-356.

[7] Park J, Zheng W. Human exposure and health effects of inorganic and elemental mercury. J. Prev. Med. Public Health 2012; 45: 344-352.

[8] Sundseth K, Pacyna J, Pacyna E, Pirrone N, Thorne R. Global sources and pathways of mercury in the context of human health. Int. J. Environ. Res. Public Health 2017; 14: 1-14.

[9] Ferrara R. Mercury mines in Europe: Assessment of emissions and environmental contamination. In: Ebinghaus R, Turner R, de Lacerda L, Vasiliev O, Salomons W, eds. Mercury Contaminated Sites. Environmental Science. Springer, Berlin, Heidelberg, 1999.

[10] Loredo J, Soto J, Álvarez R, Ordóñez A. Atmospheric monitoring at abandoned mercury mine sites in Asturias (NW Spain). Environ. Monit. Assess. 2007; 130: 201214.

[11] Williams T, Weeks J, Apostol A, Miranda C. Assessment of mercury contamination and human exposure associated with coastal disposal of waste from a cinnabar mining operation, Palawan, Philippines. Environ. Geol.1999; 39(1): 51-60.

[12] Gray J, Greaves I, Bustos D, Krabbenhoft D. Mercury and methylmercury contents in mine-waste calcine, water, and sediment collected from the Palawan Quicksilver Mine, Philippines. Environ. Geol. 2003; 43: 298-307.

[13] Samaniego J, Gibaga CR, Tanciongco A, Rastrullo R. Total Mercury in Soils and Sediments in the Vicinity of Abandoned Mercury Mine Area in Puerto Princesa City, Philippines. Applied Sciences 2020; Accepted manuscript.

[14] Samaniego J, Gibaga CR, Tanciongco A, Rastrullo R and Costa MA. Surface water characteristics in the vicinity of abandoned mercury mine site in Puerto Princesa City, Philippines. Philippine Journal of Science 2019; 148(3): 493-498. 
[15] Maramba N, Reyes J, Francisco-Rivera A, Panganiban L, Dioquino C, Dando N, Timbang R, Akagi H, Castillo M, Quitoriano C, Afuang M, Matsuyama A, Eguchi T, Fuchigami Y. Environmental and human exposure assessment monitoring of communities near an abandoned mercury mine in the Philippines: A toxic legacy. J. Environ. Manag. 2006; 81: 135-145.

[16] Horvat M, Nolde N, Fajon V, Jereb V, Logar M, Lojen S, Jacimovic R, Falnoga I, Liya Q, Faganeli J, Drobne D. Total mercury, methylmercury and selenium in mercury polluted areas in the province Guizhou, China. Sci. Total Environ. 2003; 304: 231-256.

[17] Vaselli O, Higueras P, Nisi B, María Esbrí J, Cabassi J, Martínez-Coronado A, Tassi F, Rappuoli D. Distribution of gaseous $\mathrm{Hg}$ in the mercury mining district of Mt. Amiata (Central Italy): A geochemical survey prior the reclamation project. Environ. Res. 2013; 125: 179-187.

[18] Gomez M, Klink J, Boffetta P, Espanol S, Sallsten G, Quintana J. Exposure to mercury in the mine of Almaden. Occup. Environ. Med. 2007; 64: 389-395.

[19] Jen Y, Chen W, Hung C, Yuan C, Ie I. Field measurement of total gaseous mercury and its correlation with meteorological parameters and criteria air pollutants at a coastal site of the Penghu Islands. Aerosol Air Qual. Res. 2014; 14: 364-375.

[20] PAGASA. Climate Types of the Philippines. Philippine Atmospheric, Geophysical and Astronomical Services Administration, Quezon City, Philippines, 2010. Available

at http://bagong.pagasa.dost.gov.ph/information/climatephilippines.

[21] Melendez-Perez J, Fostier A. Assessment of Direct Mercury Analyzer ${ }^{\circledR}$ to quantify mercury in soils and leaf samples. J. Brazil Chem. Soc. 2013; 24(11): 1880-1886.

[22] Windmoller C, Silva N, Andrade M, Mendes L, Magalhaes do Valle $\mathrm{C}$. Use of a direct mercury analyzer ${ }^{\circledR}$ for mercury speciation in different matrices without sample preparation. Anal. Methods 2017; 9: 2159-2167.

[23] Butala S, Scanlan L, Chaudhuri S. A detailed study of thermal decomposition, amalgamation/atomic absorption spectrophotometry methodology for the quantitative analysis of mercury in fish and hair. J. Food Prot. 2006; 69(11): 2720-2728.

[24] Sibson R. A brief description of natural neighbour interpolation. In: Barnett V, ed, Interpreting multivariate data. John Wiley \& Sons, New York, 1981.

[25] Schroeder W, Munthe J. Atmospheric Mercury - an overview. Atmos. Environ. 1998; 32: 809-822.

[26] Bhaskar B, Mehta V. Atmospheric Particulate Pollutants and their Relationship with Meteorology in Ahmedabad. Aerosol Air Qual. Res. 2010: 10: 301-315.

[27] García-Sánchez A, Murciego A, Álvarez-Ayusoa E, Santa Regina I, Rodríguez-González M. Mercury in soils and plants in an abandoned cinnabar mining area (SW Spain). J. Hazard. Mater. 2009; 168: 1319-1324.

[28] Lindberg S, Kim Y, Meyers T, Owens J. A micrometeorological gradient approach for quantifying air/surface exchange of mercury vapour: Tests over contaminated soils. Environ. Sci. Technol. 1995; 29: 126-135.

[29] Engle M, Gustin M. Scaling of atmospheric mercury emissions from three naturally enriched areas: Flowery Peak, Nevada; Peavine Peak, Nevada; and Long Valley Caldera, California. Sci. Total Environ. 2002; 290: 91104.

[30] Gustin M, Taylor G, Maxey R. Effect of temperature and air movement on the flux of elemental mercury from substrate to the atmosphere. J. Geophys. Res. 1997; 102: 3891-3898.

[31] Jaenicke R. Tropospheric Aerosols. Int. Geophys. Ser. 1993; 54: 1-31.

[32] Lindberg S, Zhang H, Gustin M, Vette A, Marsik F, Owens J, Casimir A, Ebinghaus R, Edwards G, Fitzgerald C, Kemp J, Kock H, London J, Majewski M, Poissant L, Pilote M, Rasmussen P, Schaedlich F, Schneeberger D, Sommar J, Turner R, Wallschliger D, Xiao Z. Increases in mercury emissions from desert soils in response to rainfall and irrigation. J. Geophys. Res. Atmos. 1999; 104(D17): 21,879-21,888.

[33] Song X, Van Heyst B. Volatilization of mercury from soils in response to simulated precipitation. Atmos. Environ. 2005; 39: 7494-7505. 